\title{
Spectrofluorimetric Determination of Bisphosphonates with a Fluorescent Chemosensor, Zinpyr-1·2Zn ${ }^{2+}$
}

\author{
Yunseong Jeong, Geun-woo Jin, Seul Ki Kim, Juyoung Yoon, ${ }^{\dagger, *}$ and Jong-Sang Park* \\ Department of Chemistry, College of Natural Science, Seoul National University, Seoul 151-742, Korea \\ *E-mail: pfjspark@plaza.snu.ac.kr \\ ${ }^{\dagger}$ Department of Chemistry and Nano Science (BK 21) and Department of Bioinspired Science, Ewha Womans University, \\ Seoul 120-750, Korea. E-mail: jyoon@ewha.ac.kr \\ Received October 15, 2010, Accepted November 16, 2010
}

Key Words: Chemosensor, Fluorescent chemosensor, Bisphosphonate, Alendronate, Risedronate

Because of their interference on bone resorption, various types of bisphosphonates are used in the treatment of bone metastasis and several bone disorders such as Paget's disease; osteoporosis in postmenopausal women. ${ }^{1,2}$ Because of the very low therapeutic range of the concentration of bisphosphonates via the intravenous or transdermal administration, the quantitative estimation of bisphosphonates is not easy work; therefore, many studies have been reported to develop various sensitive analytical methods for low concentrations of bisphosphonates in the blood. ${ }^{3-8}$ We had proved that a fluorescent chemosensor (FCS), NadDPA-2Zn ${ }^{2+}$, which is used for the recognition of certain molecules or ions, can be a useful analytical tool for the determination of bisphophonates in a previous study. ${ }^{9}$

However, the direct application of NadDPA- $2 \mathrm{Zn}^{2+}$ chemosensing on biological samples (e.g. blood, serum, urine and plasma) has been somewhat limited due to its relatively low solubility $(2.3 \mathrm{mg} / \mathrm{mL})$ in aqueous solution. Limited stability of NadDPA-2 $\mathrm{Zn}^{2+}$ in aqueous solution (half-life $=33$ days in HEPES buffer ( $\mathrm{pH} 7.4 ; 0.01 \mathrm{M}$ at room temp.)) provokes storage problems. Development of more soluble and stable FCS is required for the practical measurement of bisphosphonates in biological samples. Among other FCSs, Zinpyr- $1 \cdot 2 \mathrm{Zn}^{2+}$, may be a useful substitute of NadDPA-2 $\mathrm{Zn}^{2+}$ due to its higher solubility $(6.4 \mathrm{mg} / \mathrm{mL})$ and better molecular stability with longer half-life (79 days). Zinpyr-1.2 $\mathrm{Zn}^{2+}$ had been used for the determination of pyrophosphate (PPi) concentration; the signaling molecule resulted from the decomposition of adenosine triphosphate (ATP) to adenosine monophosphate (AMP).

Zinpyr- $1 \cdot 2 \mathrm{Zn}^{2+}$ (host)-PPi (guest) complexes exhibit strong fluorescence and can be analyzed using a spectrofluorometer. ${ }^{11-13}$ The 4 oxygens of bisphosphonates can bind to Zinpyr- $1 \cdot 2 \mathrm{Zn}^{2+}$ with the same coordination (Fig. 1a) on the base of the structural similarity between the P-C-P frame of the bisphosphonate and the P-O-P frame of $\mathrm{PPi}^{9}{ }^{9}$ The association constant $\left(K_{a}\right)$ of the Zinpyr-1.2Zn ${ }^{2+}$-bisphosphonate complex might be similar to that of the Zinpyr-1.2Zn ${ }^{2+}$-PPi complex, which is approximately $10^{5} .^{10} \mathrm{Zinpyr}-1 \cdot 2 \mathrm{Zn}^{2+}$ is introduced as another useful tool for the analysis of bisphosphonates in this communication. Alendronate and risedronate were selected as the test drugs.

The profile of the fluorescent titration (Fig. 1c) demonstrated that Zinpyr-1.2Zn ${ }^{2+}$ is a chemosensor of enhancer type, the intensity of which increases in proportion to bisphophonates and that its proper detection wavelength is $535 \mathrm{~nm}$ under HEPES buffer
(pH 7.4; $0.01 \mathrm{M})$. Its excitation wavelength has already been reported. ${ }^{10}$ The stoichiometric ratio of FCS (Zinpyr- $\left.1 \cdot 2 \mathrm{Zn}^{2+}\right)$ and bisphosphonate (alendronate or risedronate) in complexes with different mole fractions of bisphosphonate was estimated by using Job's method of continuous variation. The Job's plot was obtained after stock solutions A ( $50 \mu \mathrm{M}$ bisphosphonate/HEPES buffer; $\mathrm{pH} 7.4 ; 0.01 \mathrm{M})$ and $\mathrm{B}\left(50 \mu \mathrm{M}\right.$ Zinpyr-1.2 $\mathrm{Zn}^{2+} / \mathrm{HEPES}$ buffer; $\mathrm{pH} 7.4 ; 0.01 \mathrm{M}$ ) were prepared. These two solutions were mixed in ratios (by volume, A:B) of 0:10, 1:9, 2:8, 3:7, 4:6, 5:5, $6: 4,7: 3,8: 2,9: 1$, and 10:0 following which they were analyzed using a spectrofluorometer (FT-650; Jasco, Japan) with excitation and emission wavelengths of $517 \mathrm{~nm}$ and $535 \mathrm{~nm}$, respectively. As a result, the Job plots of Zinpyr- $1 \cdot 2 \mathrm{Zn}^{2+}$ with alendronate and risedronate (Fig. 1b) showed the highest value at a mole fraction of 0.5 , which confirmed that the ratio of Zinpyr$1.2 \mathrm{Zn}^{2+}$ to bisphosphonate in the complex was $1: 1$; this explains that a bisphosphonate molecule can bind with a Zinpyr-1.2 $\mathrm{Zn}^{2+}$ molecule in the same manner as that in which it binds with the PPi-Zinpyr- $1 \cdot 2 \mathrm{Zn}^{2+}$ complex.

Linearity, level of detect/limit of quantitation (LOD/LOQ) values, accuracy (recovery), and precision of the FCS (Zinpyr$1 \cdot 2 \mathrm{Zn}^{2+}$ )-based analysis of bisphosphonates were confirmed from the analysis of the calibration curve of the fluorescence, after the following procedure. The stock solutions, namely, $\mathrm{C}$ ( $1 \mathrm{mg} / \mathrm{mL}$ bisphosphonate, $1 \mu \mathrm{M}$ Zinpyr-1.2Zn ${ }^{2+} / \mathrm{HEPES}$ buffer; $\mathrm{pH} 7.4 ; 0.01 \mathrm{M})$ and D $\left(1 \mu \mathrm{M}\right.$ Zinpyr- $1 \cdot 2 \mathrm{Zn}^{2+} /$ HEPES buffer; $\mathrm{pH} 7.4 ; 0.01 \mathrm{M}$ ) were prepared; next, standard solutions in the concentration range of $0.01-2.5 \mu \mathrm{g} / \mathrm{mL}$ were prepared by mixing of two stock solutions. The fluorescence of each solution was then analyzed using a spectrofluorometer. The obtained results were used to construct a calibration curve and to confirm the LOD and LOQ values. As a result, a linear relationship

Table 1. Linearity, range, LOD, and LOQ. The equations of the calibration curve were obtained from 9 points. LOD and LOQ were defined as the concentrations of at $3 \times \mathrm{S} / \mathrm{N}$ and $10 \times \mathrm{S} / \mathrm{N}$ ratios, respectively

\begin{tabular}{cccccc}
\hline Bisphosphonate Line equation & $\mathrm{R}^{2}$ & $\begin{array}{c}\text { Range } \\
(\mu \mathrm{g} / \mathrm{mL})\end{array}$ & $\begin{array}{c}\mathrm{LOD} \\
(\mu \mathrm{g} / \mathrm{mL})\end{array}$ & $\begin{array}{c}\mathrm{LOQ} \\
(\mu \mathrm{g} / \mathrm{mL})\end{array}$ \\
\hline Alendronate $\begin{array}{r}\mathrm{y}=110.72 \mathrm{X} \\
+27.5\end{array}$ & 0.9931 & $0.01 \sim 2.5$ & 0.107 & 0.356 \\
Risedronate $\begin{array}{r}\mathrm{y}=103.01 \mathrm{X} \\
+32.1\end{array}$ & 0.9944 & $0.01 \sim 2.5$ & 0.098 & 0.326 \\
\hline
\end{tabular}


Table 2. Accuracy and precision of FCS(Zinpyr- $1 \cdot 2 \mathrm{Zn}^{2+}$ ) for alendronate and risedronate under HEPES buffer $(\mathrm{pH} 7.4 ; 0.01 \mathrm{M})$. RSD = Deviation/Average $\times 100$

\begin{tabular}{ccccc}
\hline Sample $(\mathrm{n}=9)$ & $\begin{array}{c}\text { Mixed } \\
(\mu \mathrm{g} / \mathrm{mL})\end{array}$ & $\begin{array}{c}\text { Found } \\
(\mu \mathrm{g} / \mathrm{mL})\end{array}$ & $\begin{array}{c}\text { Recovery } \\
(\%)\end{array}$ & RSD (\%) \\
\hline Alendronate & 0.5 & 0.492 & 98.4 & 3.2 \\
& 1.0 & 0.992 & 99.2 & 2.9 \\
Risedronate & 0.5 & 0.509 & 101.8 & 2.2 \\
& 1.0 & 0.989 & 98.9 & 2.5 \\
\hline
\end{tabular}

(a)
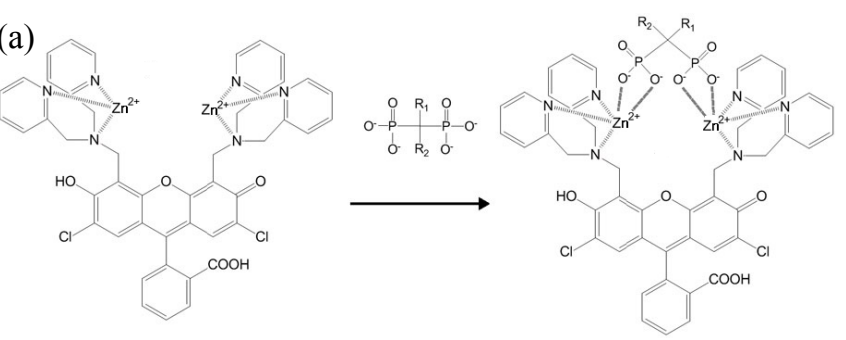

(b)

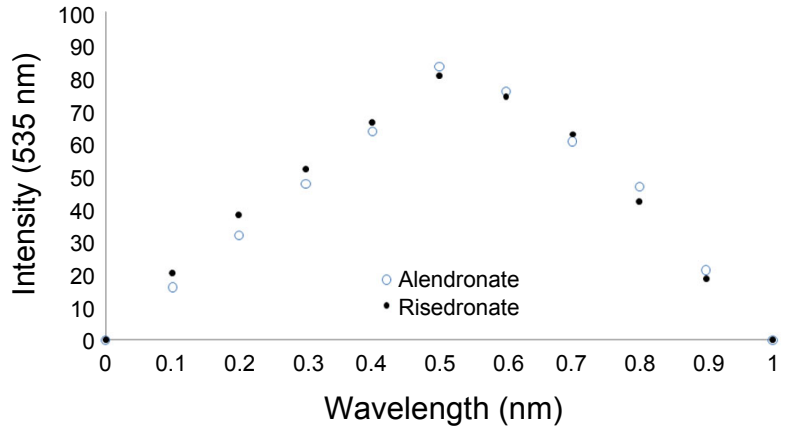

(c)

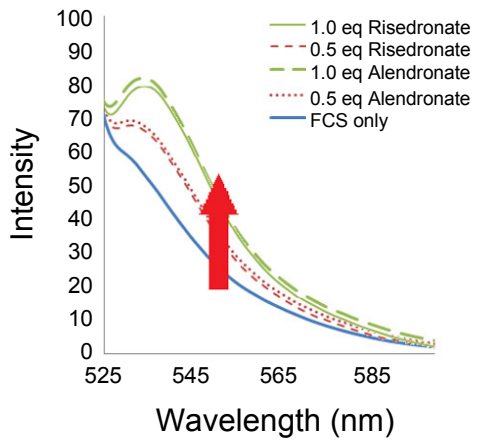

Figure 1. (a) Schematic illustration of the formation of FCS (Zinpyr$1.2 \mathrm{Zn}^{2+}$ )-bisphosphonate complex (Groups $\mathrm{R}_{1} \& \mathrm{R}_{2}$ are mentioned in the reference [9]). (b) Job's plots for bisphosphonate-Zinpyr-1.2Zn ${ }^{2+}$ complex ( 0 : alendronate, $\bullet$ : risedronate) dissolved in HEPES ( $\mathrm{pH}$ 7.4; $0.01 \mathrm{M})$. (c) Fluorescent titrations of Zinpyr- $1 \cdot 2 \mathrm{Zn}^{2+}(1 \mathrm{uM})$ with alendronate and risedonate in HEPES $(\mathrm{pH} 7.4 ; 0.01 \mathrm{M})($ Excitation/Emi$\operatorname{ssion}=517 \mathrm{~nm} / 535 \mathrm{~nm}$ ).

was obtained between the fluorescence emission and the alendronate (or risedronate) concentration over a concentration range of $0.01-2.5 \mu \mathrm{g} / \mathrm{mL}$. As shown in Table 1 , the $\mathrm{R}^{2}$ values are 0.9931 (alendronate) and 0.9944 (risedronate). The LOD, defined as the concentration at a signal-to-noise ratio of 3:1, was $0.107 \mu \mathrm{g} / \mathrm{mL}$ for alendronate and $0.098 \mu \mathrm{g} / \mathrm{mL}$ for risedronate. LOQ, defined as the concentration at a signal-to-noise ratio of
$10: 1$, was $0.356 \mu \mathrm{g} / \mathrm{mL}$ for alendronate and $0.326 \mu \mathrm{g} / \mathrm{mL}$ for risedronate. For each determination, the noise value was determined from the standard deviation value of a blank solution ( $1 \mu \mathrm{M}$ Zinpyr-1.2Zn ${ }^{2+}$ only). The LOD and LOQ values of Zinpyr- $1 \cdot 2 \mathrm{Zn}^{2+}$ are higher than those of NadDPA- $2 \mathrm{Zn}^{2+}$; It might be the reason that the association constant $\left(K_{a}\right)$ of the former is lower than that of the latter according to the reported studies of FCS-PPi complexation. ${ }^{10}$

The accuracy and precision of this method was confirmed after the preparation of bispbospbonate-mixed solutions (with a sample volume of $2 \mathrm{~mL}$ for each solution) with concentrations of 0.5 and $1.0 \mu \mathrm{g} / \mathrm{mL}$ using the HEPES buffer $(\mathrm{pH} 7.4 ; 0.01 \mathrm{M}$ ) followed by the addition of $1 \mu \mathrm{L}$ of $2 \mathrm{mM}$ Zinpyr- $1 \cdot 2 \mathrm{Zn}^{2+}$ / HEPES buffer (pH 7.4; $0.01 \mathrm{M}$ ). Table 2 summarizes the results as the average of nine independent experiments through the 'Found values' which are the recovered concentrations of bisphosphonates As compared to the original concentration (mixed value), the recovery percentage was calculated to be in the range of $97.8 \%-100.8 \%$, and the relative standard deviations (RSDs) of the recovery rate were in the range of $2.2 \%-3.2 \%$. This method is expected to have sufficient reliability and reproducibility for use in detailed analysis.

In summary, a fluorescent chemosensor (FCS)-based measurement method for measuring bisphosphonate levels using Zinpyr- $1 \cdot 2 \mathrm{Zn}^{2+}$ was developed as an applicable tool for biological samples. Furthermore, easier, more accurate and sensitive measurement of bisphosphonates in biological samples can be achieved after the development of FCS containing more stable chromophore with a higher extinction coefficient and quantum yield.

\section{References}

1. Shaw, N. J.; Bishop, N. J. Arch. Dis. Child. 2005, 90, 494.

2. Serge C. L. M. Cremers; Ruud van Hogezand; Denise Bänffer; Jan den Hartigh; Pieter Vermeij; Socrates E. Papapoulos; Neveen A. T. Hamdy, Osteoporos Int. 2005, 16, 1727.

3. B. Mallikarjuna Raoa; M.K. Srinivasua; Ch. Prathima Rania; S. Siva kumara; P. Rajender Kumarb; K.B. Chandrasekharc; M. Veerender, J. Pharm. Biomed. Anal. 2005, 39, 781.

4. Eric W. Tsai; Steven D. Chamberlin; Richard J. Forsyth; Carrie Bell; Dominic P. Ip, Marvin A. Brooks, J. Pharm. Biomed. Anal. 1994, 12, 983.

5. Quitasol, J.; Krastins, L. J. Chromatogr. A 1994, 671, 273.

6. Hui-Juan Jia; Wei Li; Kang Zhao, Anal. Chim. Acta 2006, 562 , 171.

7. Joseph D. De Marco; Stephen E. Biffar; David G. Reed; Marvin A. Brooks, J. Pharm. Biomed. Anal. 1989, 7, 1719.

8. Kline, W. F.; Matuszewski, B. K. J. Chromatogr. 1992, 583, 183.

9. Jeong, Y.; Kim, S. Y.; Jin, G.-w.; An, S.; Lee, J. H.; Jeong, A-r.; Choi, Y.; Hong, J.-I.; Park, J.-S. Bull. Korean Chem. Soc. 2010 , 31( 9), 2561.

10. Jang, Y. J.; Jun, E. j.; Lee, Y. J.; Kim, Y. S.; Kim, J. S.; Yoon, J. J. Org. Chem. 2005, 70, 9603.

11. Kim, S. K.; Lee, D. H.; Hong, J.-I.; Yoon, J. Acc. Chem. Res. 2009, $42,23$.

12. Kim, S. K.; Seo, D.; Han, S. J.; Son, G.; Lee, I.-J.; Lee, C.; Lee, K. D.; Yoon, J. Tetrahedron 2008, 64, 6402.

13. Lee, D. H.; Kim, S. Y.; Hong, J.-I. Tetrahedron Lett. 2007, 48, 4477. 